\title{
Comparison of Physical and Physiological Performance Features of Parkour and Gymnastics Athletes
}

\author{
Sinan Seyhan ${ }^{1}$ \\ ${ }^{1}$ Faculty of Sport Sciences, Celal Bayar University, Manisa, Turkey \\ Correspondence: Sinan Seyhan, Faculty of Sport Sciences, Celal Bayar University, Halil Erdogan St. 45040, \\ Manisa, Turkey. E-mail: sinan.seyhan@cbu.edu.tr or sinanseyhan@gmail.com
}

Received: January 21, 2019

Accepted: February 16, 2019 Online Published: February 25, 2019

doi:10.5539/jel.v8n2p111

URL: https://doi.org/10.5539/jel.v8n2p111

\begin{abstract}
The purpose of this study was to compare the physical and physiological features of the traceurs with the gymnastics athletes. The study was carried out with twelve volunteer participants (traceurs $=6$, gymnastics athletes $=6$ ). The mean age of the traceurs was $18.67 \pm 1.03$ years, $172.67 \pm 3.78 \mathrm{~cm}$, body mass $62.5 \pm 8.94 \mathrm{~kg}$ and BMI was 20.98 \pm 2.97 ; gymnastics athletes was $19.33 \pm 1.21$ years, $175.83 \pm 6.18 \mathrm{~cm}$, body mass $65.17 \pm 8.06 \mathrm{~kg}$ and BMI was $21.11 \pm 2.67$. Maximal oxygen utilization levels of traceurs and rhythmic gymnastics athletes were $56.13 \pm 3.95 \mathrm{ml} / \mathrm{kg} / \mathrm{min}$ and $57.18 \pm 5.33 \mathrm{ml} / \mathrm{kg} / \mathrm{min}$ respectively, their Illinois test times were $15.22 \pm .42 \mathrm{sec}$ and $15.33 \pm .22 \mathrm{sec}$ respectively, their vertical jump distances were $47.41 \pm 6.05 \mathrm{~cm}$ and $46.48 \pm 3.37 \mathrm{~cm}$ respectively, their vertical jump power values were $7252.7 \pm 1142.73 \mathrm{~W}$ and $7026.55 \pm 427.62 \mathrm{~W}$ respectively, their horizontal jump distances were $2.53 \pm .61 \mathrm{~m}$ and $2.48 \pm .12 \mathrm{~m}$ respectively, and finally, their hamstring flexion angles were determined by using goniometer as the measurement of hamstring flexibility (traceurs $=106.67 \pm 4.27^{\circ}$; gymnastics athletes $=121.33 \pm 5.36^{\circ} *$ ), and there was a significant difference between the angles hamstring flexibility of the two groups $\left({ }^{*} \mathrm{p}<0.05\right)$. According to the results obtained from the study, it was seen that physical and physiological values obtained from two groups of athletes were very close to each other and no significant difference was observed between these two groups. This similarity can be explained by the fact that the training of these two branches does not differ as structural features. In conclusion, the learning of important performance determinants in athletes, such as aerobic power, flexibility, agility and explosive power, by the coaches and their education in this subject may enable the preparation of a better training program.
\end{abstract}

Keywords: parkour, gymnastics, physiological performance

\section{Introduction}

According to its founders, the parkour, which spread from the back streets of France all over the world, is the art of moving in a fluent manner, aiming to go from one place to another, including a variety of movements such as swinging, jumping, balancing, running in order to pass under and over any obstacle, taking into account the conditions of the environment. In doing so, they must find new and potentially dangerous ways to pass obstacles. Traceurs should have good physical structure, flexibility and all other physical and physiological structures in order to be able to perform jumps and take-offs from walls and buildings through acrobatic movements (McLean, Houshian, \& Pike, 2006; Larsen, 2015; Grosprete \& Lepers, 2016). There are special movements that form the basis of parkour sport and are specific to this sport. These movements are particularly closely related to gymnastic movements, have their own rules, and contain the basic movements of sports branches such as gymnastics and athletics. There is no need for any material requirements for the realization of these activities. In order to overcome the obstacles in the city or natural conditions, it is possible for them to be successful by fulfilling some of the requirements of gymnastics and athletics (Grosprete, Ufland, \& Jecker, 2018).

In the literature, there is not many studies about this newly developing sport. It is known that the traceurs, who are engaged in this sport, imrpove their physical, physiological, and especially muscle skills thanks to the parkour applications and they contribute significantly to the jump capacity. Thanks to the parkour applications, traceurs provide better resistance to high eccentric load. Thus, these studies help to strengthen and improve their musculoskeletal structures (Grospretre \& Lepers, 2016). It is especially important for the performances of the athletes that the traceurs use the specific landing techniques and develop their lower extremity muscles while knowing the specific rules of the sport (Puddle \& Maulder, 2013). It is known that these applications increase the 
lower extremity strength of the traceurs and contribute to the development of the plyometric features (Dvorak, Eves, Bunc, \& Balas, 2017). In other words, for all athletes, aerobic and anaerobic power, speed, stamina, flexibility, coordination and skill are known to be the physical and physiological elements that influence the success (Akgun, 1986).

Together with the sports scientists, in order to evaluate and improve the athletic performance, coaches provide information on the performance of their athletes by performing physical-physiological performance tests and body structure measurements. Indicative of the successful performance, the physical and physiological features of the athletes who are interested in gymnastics sport, which forms the basis of the movements of traceurs and which is one of the branches that involve special technique applications as well as a great number of jumps, are considered to show some differences. The successful performance of the athletes who are interested in the parkour and gymnastics branches are closely associated with having physical and physiological features required by these branches (Hume et al., 1993).

Strength, power, flexibility, stamina and quickness are important determinants for the successful performance of athletes. Therefore, the purpose of this study is to acquire information about physical and physiological performance features of the gymnastics athletes together with the traceurs, and to compare the two sports branches with the results obtained.

\section{Method}

This study was carried out with twelve volunteer participants, 6 traceurs and 6 gymnastics athletes. Participants were informed about the purpose and method of the study before starting the study. The study included individuals who were older than 18 and were engaged in parkour and gymnastics sports for at least 2 years.

Height and body weight, and then physiological performance compliance tests were performed as the descriptive data of the athletes.

\section{Data Collection}

-Height: In anatomical posture, with bare feet, joined heels, head in the frontal plane, overhead level touching the vertex point, while the subject is holding the breath, the heights of the athletes was measured with a stadiometer (Seca, Germany) that has a precision of $0.01 \mathrm{~m}$ and the values were recorded in $\mathrm{cm}$.

-Body Weight: In anatomical posture, with bare feet and only shorts being worn, the body weights of the athletes were measured with a stadiometer (Seca, Germany) that has a precision of $0.01 \mathrm{~m}$ and the values were recorded in $\mathrm{kg}$.

-illinois Agility Test: This test, which is used to determine the agility feature of the participants, was performed in $5 \mathrm{mx} 10 \mathrm{~m}$ area by placing cones at certain points (the starting point, $10 \mathrm{~m}$ opposite to the starting point, the finish line and 10m opposite to the finish line). After a warm-up of 5-6 minutes, the test was repeated 2 times (Figure 1). The chronometer was used to determine the test completion time. Two measurements were made for the participants and the best score was recorded (Aynes \& Alacid, 2016).

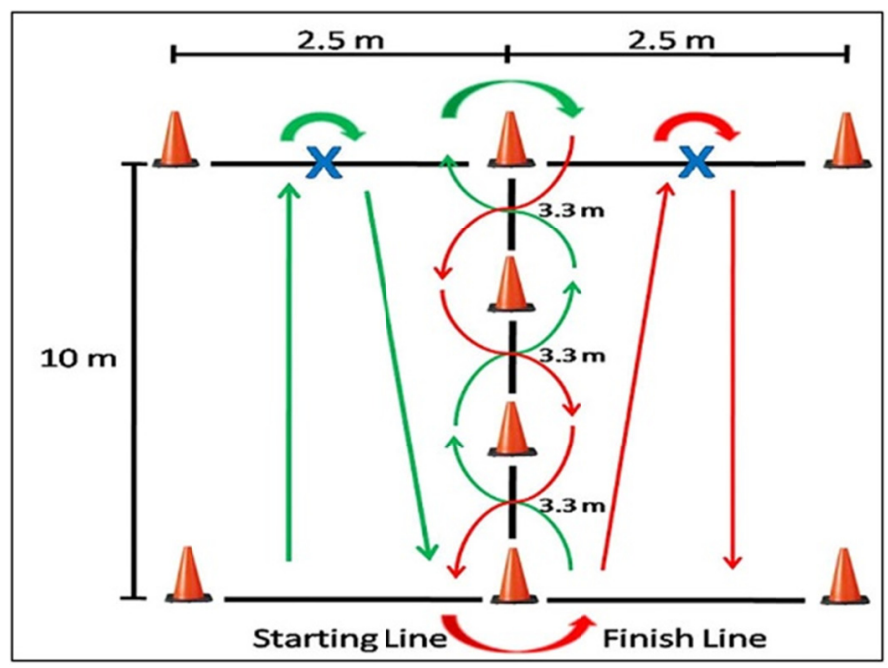

Figure 1. İllinois agility test 
-Hamstring Flexibility Test: The goniometer (Uick 360 Digital Angle Rule) was used to determine the hamstring flexibility of the participants. The participant was laid on a flat surface and his/her legs were elevated up to 90 degrees at the hip flexion in the goniometer. Taking the trochanter major as a reference, the movable tip of the goniometer was placed parallel to the body's movement area. The other part was placed on the non-moving section of the extremity. The participant was asked to stretch the dominant leg to the final point in the direction of movement, in which the joint opening would be measured. The movement angle of the joint was determined by goniometer and the hamstring flexibility value was recorded in degrees (Tamer, 2000).

-Countermovement and Squat Jump Test: The participants were applied a standard 10-minute warm-up consisting of running, lower extremity dynamic warm-up movements and vertical jumps in order to prevent injuries. Using the iPhone 7 mobile phone (Apple Inc USA), each participant's vertical jumps were recorded with the high-speed camera in the validated My Jump 2 application (Balsalobre-Fernandez, Glaister, \& Lockey, 2015). Each participant was asked to do vertical jumps 3 times as high as possible. At the end of each jump, a passive rest period of 2 minutes was given. In the video, the participants' take-offs and landings were determined. Then, the jump distance was calculated using the equation $\left(h=t^{2} \times 1.22625\right)$ which determines the jump height. The same procedure was also applied in the horizontal jump. The best results were considered in the evaluation (Bosco, Luhtanen, \& Komi, 1983).

-Shuttle Run Test: This test is also known as the endurance test, which includes non-stop running at an initial speed of $8 \mathrm{~km} / \mathrm{h}$ on a $20 \mathrm{~m}$ parkour, increasing $0.5 \mathrm{~km} / \mathrm{h}$ every $1 \mathrm{~min}$. The running tempo was determined by a time counter and signal tone. Each participant must be within the resting lines to complete the $20 \mathrm{~m}$ parkour in each signal. The test was terminated for the participant who could not reach the lines located in front of the lines that defined $20 \mathrm{~m}$ when the signal was heard twice in succession. Aerobic power value was determined from $\mathrm{VO}_{2 \max }$ estimation table according to the number of shuttle running (Tong et al., 1995).

\section{Data Analysis}

SPSS 21 program was used in the statistical analysis of this study. Statistical analysis revealed that the data were not distributed normally when the number of participants was taken into consideration. Therefore, nonparametric tests were performed. The data obtained from the participants, the descriptive features of the participants (age, height, weight, BMI), the arithmetic means (X), the standard deviations (SD) were analyzed and Mann-Whitney $\mathrm{U}$ test was performed to reveal the difference between groups.

\section{Results}

The descriptive statistics of the participants were presented in Table 1.

Table 1. Descriptive features of participants

\begin{tabular}{lll}
\hline & Traceurs $(\mathrm{n}=6)$ & Gymnastics Athletes $(\mathrm{n}=6)$ \\
\hline Age $($ years $)$ & $18.67 \pm 1.03$ & $19.33 \pm 1.21$ \\
Height $(\mathrm{cm})$ & $172.67 \pm 3.78$ & $175.83 \pm 6.18$ \\
Weight $(\mathrm{kg})$ & $62.5 \pm 8.94$ & $65.17 \pm 8.06$ \\
BMI & $20.98 \pm 2.97$ & $21.11 \pm 2.67$ \\
\hline
\end{tabular}

Kg: Kilogram, cm: Centimeter, BMI: Body Mass Index

The mean age of the traceurs was $18.67 \pm 1.03$ years, $172.67 \pm 3.78 \mathrm{~cm}$, body mass $62.5 \pm 8.94 \mathrm{~kg}$ and BMI was $20.98 \pm 2.97$. The mean age of the gymnastics athletes was $19.33 \pm 1.21$ years, $175.83 \pm 6.18 \mathrm{~cm}$, body mass $65.17 \pm 8.06 \mathrm{~kg}$ and BMI was 21.11 \pm 2.67 .

The body compositions and anthropometric features of the participants were presented in Table 2 below.

Table 2. Physical and Physiological performance levels of participants (mean $\pm \mathrm{sd}$ )

\begin{tabular}{llll}
\hline & Traceurs $(\mathbf{n}=\mathbf{6})$ & Gymnastics Athletes $(\mathbf{n}=\mathbf{6})$ & Total $(\mathbf{n}=\mathbf{1 2})$ \\
\hline $\mathrm{Vo}_{2 \max }(\mathrm{ml} / \mathrm{kg} / \mathrm{min})$ & $56.13 \pm 3.95$ & $57.18 \pm 5.33$ & $56.66 \pm 4.51$ \\
Illinois test (s) & $15.22 \pm .42$ & $15.33 \pm .22$ & $15.28 \pm .32$ \\
Hamstring Flexibility Measurement $\left({ }^{\circ}\right)$ & $106.67 \pm 4.27$ & $121.33 \pm 5.36^{*}$ & $114 \pm 4.82$ \\
Vertical Jump & $47.41 \pm 6.05$ & $46.48 \pm 3.37$ & $46.94 \pm 4.69$ \\
Vertical Jump Power (W) & $7252.7 \pm 1142.73$ & $7026.55 \pm 427.62$ & $7139.62 \pm 831.04$ \\
Horizontal Jump (m) & $2.53 \pm .61$ & $2.48 \pm .12$ & $2.51 \pm .09$ \\
\hline
\end{tabular}

$\mathrm{VO}_{2 \max }$ : Maximum amount of oxygen consumed per kilogram of body $\left(\mathrm{ml} \cdot \mathrm{dk}^{-1} \cdot \mathrm{kg}^{-1}\right), \mathrm{s}$ : Second, ${ }^{\circ}$ : Degree, W: Power, m: Meter, $* \mathrm{P}<0.05$ 
It is seen that the results of $\mathrm{VO}_{2 \max }$, Illinois test (Agility), Vertical Jump Power and Horizontal Jump are very close values.

When the physical and physiological performance levels of the participants were examined, the $\mathrm{VO}_{2 \max }$ values of the traceurs and gymnastics athletes were $56.13 \pm 3.95 \mathrm{ml} / \mathrm{min}^{-1} \mathrm{~kg}^{-1}$ and $57.18 \pm 5.33 \mathrm{ml} / \mathrm{min}^{-1} \mathrm{~kg}^{-1}$ respectively, their Illinois test times were $15.22 \pm .42 \mathrm{sec}$ and $15.33 \pm .22 \mathrm{sec}$ respectively, their vertical jump values were $47.41 \pm 6.05 \mathrm{~cm}$ and $46.48 \pm 3.37 \mathrm{~cm}$ respectively, their vertical jump power values were $7252.7 \pm 1142.73 \mathrm{~W}$ and $7026.55 \pm 427.62 \mathrm{~W}$, their horizontal jump distances were $2.53 \pm .61 \mathrm{~m}$, and finally, their hamstring flexibility measurements were $106.67 \pm 4.27^{\circ}$ and $121.33 \pm 5.36^{\circ}$ respectively. A significant difference was found between the two participant groups in terms of flexibility measurements (traceurs $=106.67 \pm 4.27^{\circ}$; gymnastics athletes $=$ $\left.121.33 \pm 5.36^{\circ} *\right)(* \mathrm{p}<0.05)$.

\section{Discussion and Conclusion}

It is very important for athletes to know their physical and physiological features in terms of their performance. Therefore, the purpose of this study was to compare the physical and anthropometric features of the traceurs with the gymnastics athletes who perform jumping and falling movements very often.

According to the results obtained from the study, it was seen that the data values obtained from two groups of athletes were very close to each other and there was no significant difference between the two groups. When the hamstring flexibility measurement performances of the traceurs and gymnastics athletes were examined, it was determined that there was a significant difference between the hamstring flexibility measurements of the two participants (traceurs; $106.67 \pm 4.27^{\circ}$, gymnastics athletes; $121.33 \pm 5.36^{\circ} *$ ). $\left({ }^{*}<0.05\right.$ ). The reason for this difference can be explained as the fact that the traceurs give more importance to the exercise strength than to flexibility. In one of the studies related to hamstring flexibility measurements in the literature, which was conducted on forty male students-athletes in the evaluation of hamstring flexibility with the Myrin goniometer, the degree score was $88.00 \pm 2.26^{\circ}$, while the mean right leg flexibility scores of 102 participants were determined as 76.5 $\pm 9.5^{\circ}$ in another study (Bakirtzoglou, Ioannou, and Bakirtzoglou 2010; Baltaci et al., 2003).

In a previous study, it was observed that the mean $\mathrm{VO}_{2 \max }$ values of the traceurs were $63.32 \pm 12.35$ (Abellan and Alacid, 2016). In this study, $\mathrm{VO}_{2 \max }$ values of traceurs and gymnastics athletes were determined as $56.13 \pm 3.95$ $\mathrm{ml} / \mathrm{min}^{-1} \mathrm{~kg}^{-1}$ and $57.18 \pm 5.33 \mathrm{ml} / \mathrm{min}^{-1} \mathrm{~kg}^{-1}$. In the study conducted by Douda et al. with 15 elite rhythmic gymnasts, the mean $\mathrm{VO}_{2 \max }$ of these athletes were found to be $54.81 \pm 2.64 \mathrm{ml} / \mathrm{min}^{-1} \mathrm{~kg}^{-1}$. These values are lower than the results obtained from the athletes participating in our study (Douda, Toubekis, Avloniti and Tokmakidis, 2008).

It can be said that the mean vertical jump values of the participants $(47.41 \pm 6.05 \mathrm{~cm})$ are very close to each other, especially when compared with gymnastics athletes $(46.48 \pm 3.37 \mathrm{~cm})$. In a study conducted by Abellan and Alacid in 2016, it was observed that the mean vertical jump height values of the participants were $43.10 \pm 7.88$ (Abellan and Alacid, 2016). In another study, the mean vertical jump values of elite male gymnastics athletes were found to be $40.10 \pm 1.2 \mathrm{~cm}$ (Jensen, Scott, Krustrup and Mohr, 2013). In the literature, it can be said that the results of the previous study are much lower than the data obtained from the traceurs in this study. In addition to these results, there was no significant difference between vertical jump power values $(7252.7 \pm 1142.73 \mathrm{~W}$ and $7026.55 \pm 427.62 \mathrm{~W})$.

When the horizontal jump distances, which are another performance test, are examined, it is seen that the mean horizontal jump distances of the football players were observed as $2.39 \pm 0.14 \mathrm{~m}$ in a study conducted with football players in the literature (Yanci, et al., 2014). In this study, mean horizontal jump distances $(2.53 \pm .61 \mathrm{~m})$ and $(2.48 \pm 12 \mathrm{~m})$ were determined respectively. In addition, there was no significant difference between the horizontal jump distances of both groups. It is known to be particularly important in terms of increasing the muscle strength of the lower extremity, and the types of sporting activities where jump and sprint activities are frequently used (Haff and Potteiger, 2001). The development of these characteristics can significantly affect the jump performance of athletes.

In a study conducted with 20 soccer players with a mean age of 24 years, it was found that the mean values of the Illinois test results (agility) were $18.007 \pm 0.688$ (Homoud, 2015). In this study, the Illinois test results of traceurs and gymnastics athletes were determined as $15.22 \pm .42 \mathrm{sec}$ and $15.33 \pm 22 \mathrm{sec}$, respectively. There was no significant difference between the Illinois test (agility) results of both groups.

As a result, the data obtained from the endurance, agility, vertical and horizontal jump performance characteristics of the traceurs and gymnastics athletes are similar. This similarity can be explained by the fact that the training of these two branches does not differ as structural features. This structural features important 
determinants of performance in athletes, the learning of important performance determinants in athletes (aerobic power, flexibility, agility and explosive power) by the coaches and their education in this subject may enable the preparation of a better training program.

\section{References}

Akgun, N. (1986). Egzersiz Fizyolojisi (2nd ed.). Ege University, Izmir.

Aynes, O. A., \& Alacid, F. (2016). Anthropometric Profile, Physical Fitness and Differences Between Performance Level Of Parkour Practitioners. Arch Med Deporte, 33(5), 312-316.

Bakirtzoglou, P., Ioannou, P., \& Bakirtzoglou, F. (2010). Evaluatıon of Hamstring Flexıbility by Using Two Different Measuring Instruments. Sport Logia, 6(2), 28-32. https://doi.org/10.5550/sgia.1002028

Balsalobre-Fernandez, C., Glaister, M., \& Lockey, R. A. (2015). The Validity and Reliability of an İphone App for Measuring Vertical Jump Performance. J. Sports Sci. 33, 1574-1579. https://doi.org/10.1080/02640414.2014.996184

Baltaci, G., Un, N., Tunay, V., Besler, A., \& Gerçeker, S. (2003). Comparison of Three Different Sit and Reach Tests for Measurement of Hamstring Flexibility İn Female University Students. Br J. Sports Med, 37, 59-61. https://doi.org/10.1136/bjsm.37.1.59

Bosco, C., Luhtanen, P., \& Komi, P. V. (1983). A Simple Method for Measurement of Mechanical Power in Jumping. European Journal of Applied Physiology and Occupational Physiology, 50(2), 273-282. https://doi.org/10.1007/BF00422166

Douda, H. T., Toubekis, G. A., Avloniti, A. A., \& Tokmakidis, P. S. (2008). Physiological and Anthropometric Determinants of Rhythmic Gymnastics Performance. International Journal of Sports Physiology and Performance, 3, 41-54. https://doi.org/10.1123/ijspp.3.1.41

Dvorak, M., Eves, N., Bunc, V., \& Balas, J. (2017). Effects of Parkour Training on Health-Related Physical Fitness in Male Adolescents. The Open Sports Sciences Journal, 10, 132-140. https://doi.org/10.2174/1875399X01710010132

Grosprete, S., Ufland, P., \& Jecker, D., (2018). The Adaptation to Standing Long Jump Distance in Parkour is Performed by the Modulation of Specific Variables Prior and During Take-Off. Mov Sport Sci/ Sci Mot. Forthcoming, 100, 27-37. https://doi.org/10.1051/sm/2017022

Grospretre, S., \& Lepers, R. (2016). Performance characteristics of Parkour practitioners: Who are the traceurs? European Journal of Sport Science, 16(5), 526-535. https://dx.doi.org/10.1080/17461391.2015.1060263

Haff, G. G., \& Potteiger, J. A. A. (2001). Brief Review: Explosive Exercises and Sports Performance. Strength and Conditioning Journal, 23(3), 13-20. https://doi.org/10.1519/00126548-200106000-00003

Homoud, A. N. M. (2015). Relatıonships Between Illınoıs Agılity Test and Reaction Time in Male Athletes. The Swedish Journal of Scientific Research, 2(3), 28-33.

Hume, P. A., Hopkins, W. G., Robinson, D. M., Robinson, S. M., \& Hollings, S. C. (1993). Predictors of Attainment in Rhythmic Sportive Gymnastics. J Sports Med Phys Fitness, 33(4), 367-377.

Jensen, P., Scott, S., Krustrup, P., \& Mohr, M. (2013). Physiological Responses and Performance in a Simulated Trampoline Gymnastics Competition in Elite Male Gymnasts. J. Sports Sci. 31(16), 1761-1769. https://doi.org/10.1080/02640414.2013.803591

Larsen, S. H. (2015). Parkour. Institutionalisering af en ny bevagelseskultur i Danmark [Parkour. The İnstitutionalization of a New Movement Culture İn Denmark]. PhD thesis, University of Southern Denmark.

McLean, C. R., Houshian, S., \& Pike, J. (2006). Paediatric Fractures Sustained in Parkour (Free Running). Injury, Int. J. Care Injured, 37, 795-797. https://doi.org/10.1016/j.injury.2006.04.119

Puddle, D. L., \& Maulder, P. S. (2013). Ground Reaction Forces And Loading Rates Associated With Parkour and Traditional Drop Landing Techniques. Journal of Sports Science \& Medicine, 12(1), 122-129.

Tamer, K. (2000). Measurement and evaluation of physical-physiological performance in sports (pp. 131-141). Ankara.

Tong, S. F., Nasrawi, F., Fanari, M. P., \& Agosti, R. (1995). Hemorhelogy during exercise: is there a microcirculatory relationship? Biorheology, 32, 400. https://doi.org/10.1016/0006-355X(95)92422-7 
Yanci, J., Los Arcos, A., Mendiguchia, J., \& Brughelli, M. (2014). Relationships Between Sprinting, Agility, One- and Two-Leg Vertical and Horizontal Jump in Soccer Players. Int J Kinesiol, 46(2), 194-201.

\section{Copyrights}

Copyright for this article is retained by the author, with first publication rights granted to the journal.

This is an open-access article distributed under the terms and conditions of the Creative Commons Attribution license (http://creativecommons.org/licenses/by/4.0/). 